\title{
PENINGKATAN HASIL BELAJAR IPA MATERI TUMBUHAN HIJAU MELALUI METODE EKSPERIMEN KELAS V SDN BABADAN SEMESTER 1 TAHUN PELAJARAN 2015/2016
}

\author{
Masanah $^{\bowtie}$ \\ SDN Babadan Bonang Demak \\ Jawa Tengah, Indonesia
}

\section{Info Artikel}

Sejarah Artikel:

Diterima Agustus 2016

Disetujui Oktober 2016

Dipublikasikan Desember 2016

\section{Keywords:}

Understanding the

concept, Learning

Outcomes, Experimental

Methods

\begin{abstract}
The results of students of class V Semester Elementary School Babadan Bonang District of Demak district in the academic year 2015/2016 on the subjects of Natural Sciences subject matter of green plants is still low. This type of research used was classroom action research using model experiments. The study consisted of two cycles of the first cycle and the second cycle. After carrying out repairs learning, student learning outcomes is increasing both the first cycle and the second cycle. For comparison, student achievement on pre cycle, students who completed their study only 4 students, or 19\%, 17 other students did not complete. On the improvement of learning first cycle, students who completed studies, has been increased to 13 from 21 students to $62 \%$. Then after the second cycle of learning improvement obtained by students who pass the study as many as 20 out of 21 students, or about $95 \%$.
\end{abstract}

\begin{abstract}
Abstrak
Hasil belajar siswa kelas V Semester I SD Negeri Babadan Kecamatan Bonang Kabupaten Demak Tahun Pelajaran 2015/2016 pada mata pelajaran Ilmu Pengetahuan Alam materi pokok tumbuhan hijau masih rendah. Jenis penelitian yang dipakai adalah penelitian tindakan kelas menggunakan model pembelajaran eksperimen. Penelitian terdiri dari dua siklus yaitu siklus I dan siklus II. Setelah melaksanakan perbaikan pembelajaran, hasil belajar siswa selalu meningkat baik siklus I maupun siklus II. Sebagai perbandingan, prestasi belajar siswa pada prasiklus, siswa yang tuntas belajarnya hanya 4 siswa atau 19\%, 17 siswa lainnya tidak tuntas. Pada perbaikan pembelajaran siklus I, siswa yang tuntas belajarnya, sudah meningkat menjadi 13 dari 21 siswa atau sekitar $62 \%$. Kemudian setelah perbaikan pembelajaran siklus II diperoleh siswa yang tuntas belajar sebanyak 20 dari 21 siswa atau sekitar $95 \%$.
\end{abstract}

(C) 2016 Universitas Muria Kudus

\begin{tabular}{lr}
\hline Alamat korespondensi: & p-ISSN 2087-9385 \\
Program Studi Pendidikan Guru Sekolah Dasar & e-ISSN 2528-696X \\
Fakultas Keguruan dan Ilmu Pendidikan Universitas Muria Kudus & \\
Kampus UMK Gondangmanis, Bae Kudus Gd. L. lt I PO. BOX 53 & \\
Kudus & \\
Tlp (0291) 438229 ex.147 Fax. (0291) 437198 & \\
E-mail: masanah@gmail.com &
\end{tabular}




\section{PENDAHULUAN}

Sekolah sebagai bagian dari lembaga penyelenggara pendidikan formal, berupaya untuk mencapai tujuan dengan meningkatkan kualitas Pendidikan Dasar. Pendidikan Dasar bertujuan memberikan bekal kemampuan dasar kepada siswa untuk mengembangkan kehidupannya, sebagai pribadi, warganegara dan anggota umat manusia serta mempersiapkan siswa untuk mengikuti pendidikan menengah, bahwa pengajaran di sekolah mempunyai kelemahankelemahan seperti didominasi oleh pengajaran hafalan di dalam kelas, tidak mendorong keterlibatan siswa dalam belajar serta metode dan cara mengajar seorang guru kurang menarik perhatian siswa dan menyenangkan siswa.

Salah satu upaya untuk meningkatkan mutu pembelajaran di sekolah yaitu peningkatkan mutu guru. Dengan demikian, maka seorang guru diharapkan memiliki kemampuan professional. Profesionalisme guru dapat dilihat dari kemampuan dalam merencanakan dan melaksanakan pembelajaran di kelas, menggunakan metode yang variatif serta media pembelajaran yang sesuai dengan materi pelajaran yang diajarkan.

Namun hal yang berbeda terjadi pada siswa kelas V SD Negeri Babadan Kecamatan Bonang Kabupaten Demak. Guru sudah berusaha penuh agar siswa dapat memahami dengan baik materi tumbuhan hijau, namun masih banyak siswa yang belum memahaminya. Berdasarkan hasil kegiatan belajar mengajar dan pengamatan pada mata pelajaran Ilmu Pengetahuan Alam (IPA) materi pelajaran tumbuhan hijau di kelas V, meningkatkan hasil tes formatif' belum berhasil sebab dari 21 siswa yang mendapat nilai $70 \mathrm{ke}$ atas hanya 4 siswa, sisanya mendapat nilai kurang dari 70.Berbagai faktor sebenarnya dapat menjadi sebab mengapa siswa belum mendapatkan nilai yang diharapkan. Diantaranya Guru kurang maksimal dalam memberikan metode pembelajaran. Guru kurang memberi perhatian terhadap siswa. Siswa tidak terfokus pada penjelasan guru. Guru kurang memotivasi siswa.

Namun dalam penelitia ini memfokuskan pada penggunaan metode yang belum pernah diterapkan yang diharapkan dapat meningkatkan hasil belajar siswa. Pemilihan metode tentu saja perlu memperhitungkan kompetensi dasar yang ingin dicapai. Dalam mempelajari IPA, khususnya materi tumbuhan hijau (proses foto sintesis pada tumbuhan), tentu akan lebih mengena jika siswa melakukan eksperimen tentang kejadian tersebut. Oleh sebab itulah, pemilihan metode eksperimen untuk meningkatkan pemahaman siswa tentang tumbuhan hijau (proses foto sintesis pada tumbuhan) dirasa sangat pas.

Menurut Roestiyah (2001:80) Metode eksperimen adalah suatu cara mengajar, di mana siswa melakukan suatu percobaan tentang sesuatu hal, mengamati prosesnya serta menuliskan hasil percobaannya, kemudian hasil pengamatan itu disampaikan ke kelas dan dievaluasi oleh guru. Penggunaan teknik ini mempunyai tujuan agar siswa mampu mencari dan menemukan sendiri berbagai jawaban atau persoalan-persoalan yang dihadapinya dengan mengadakan percobaan sendiri. Juga siswa dapat terlatih dalam cara berfikir yang ilmiah. Dengan eksperimen siswa menemukan bukti kebenaran dari teori sesuatu yang sedang dipelajarinya. Sehingga diharapkan dengan menggunakan metode eksperimen kemampuan siswa dalam memahami dan hasil belajar siswa dalam pembelajaran IPA materi tumbuhan hijau dapat ditingkatkan.

Setiap usaha dan perbuatan akan berhasil dengan baik, apabila dilandasi dengan penetapan suatu tujuan yang direncanakan secara matang dan cermat. Adapun tujuan dilaksanakan penelitian ini adalah untuk mengetahui apakah penerapan metode eksperimen dapat meningkatkan pemahaman dan hasil belajar siswa pada pembelajaran IPA tentang tumbuhan hijau di kelas V semester I SD Negeri Babadan Kecamatan Bonang Tahun Pelajaran 2015/2016.

\section{METODE PENELITIAN}

Pelaksanaan penelitian ini dilaksanakan SD Negeri Babadan Kecamatan Bonang, Kabupaten Demak. Subjek penelitian ini adalah 21 siswa kelas V ( lima ) SD Negeri Babadan yang terdiri atas 10 orang siswa laki-laki dan 11 siswa perempuan. Pelaksanaan penelitian terdapat dua siklus yaitu siklus I dan siklus II. Siklus I dilaksanakan pada bulan Oktober 2015. Dan siklus II dilaksanakan pada bulan Nopember 2015.

Sebelum melakukan sebuah perbaikan pembelajaran, peneliti perlu memiliki desain prosedur dalam melakukan perbaikan pembelajaran tersebut. Desain penelitian digunakan untuk mempermudah sekaligus sebagai acuan dalam pelaksanaan tahap demi tahap penelitian. Perbaikan penelitian yang digunakan adalah Penelitian Tindakan Kelas yang terdiri dari dua siklus. Setiap siklus meliputi perencanaan, pelaksanaan tindakan, pengamatan (observasi) dan refleksi.

Teknik pengumpulan data yang digunakan dalam penelitan ini antara lain observasi untuk menjaring data proses pembelajaran berupa aktivitas siswa di dalam pembelajaran. Tes untuk mengetahui hasil belajar siswa dan dokumentasi 
untuk mengumpulkan data yang berupa catatan penting yang berhubungan dengan masalah yang diteliti sehingga akan diperoleh data yang lengkap. Dokumentasi dalam penelitian ini diambil dari data nilai siswa kelas V Semester I SDN Babadan tahun 2015 / 2016.

Analisis data yang peneliti gunakan dalam penelitian ini adalah deskriptif kuantitatif dan deskriptif kualitatif. Data kuantitatif ini peneliti dapat dari hasil tes formatif siswa pada siklus I dan siklus II. Data tersebut penulis dapatkan dari lembar observasi, serta tes tertulis yang diberikan kepada siswa yang berupa tes formatif berjumlah 10 soal pilihan ganda dan 5 soal isian. Pada soal pilihan ganda, setiap jawaban yang benar diberikan skor 1. Sedangkan pada soal isian, setiap soal yang benar mendapat skor 2. Adapun nilai akhir adalah jumlah skor perolehan dibagi 2 kemudian dikalikan 10. Dengan demikian dapat diketahui nilai masing-masing siswa yang kemudian dijadikan sebagai data. Sedangkan analisis data deskriptif kualitatif peneliti dapatkan dari lembar pengamatan, baik dari kegiatan guru maupun kegiatan siswa.

\section{HASIL DAN PEMBAHASAN Hasil Penelitian Prasiklus}

Sebelum dilaksanakan perbaikan pembelajaran pada mata pelajaran Ilmu Pengetahuan Alam materi pokok tumbuhan hijau, hasil prasiklus yang didapati adalah dari 21 siswa hanya 4 siswa yang tuntas yaitu kelas interval 8089 sebanyak 1 siswa atau 5\% dan siswa yang mendapatkan nilai di kelas interval 70-79 hanya 3 siswa atau $14 \%$. Sedangkan sebanyak 17 siswa atau sebanyak $81 \%$ belum mencapai nilai KKM (70) yaitu sebanyak 8 siswa memeroleh nilai antara 60-69 atau sebanyak 38\%. Siswa yang memeroleh nilai dikelas interval 50-59 sebanyak 6 siswa atau sebnyak 29\%. Siswa yang memeroleh nilai di kelas interval 40-49 sebanyak 2 siswa atau $10 \%$ dan siswa yang mendapatkan nilai terendah yaitu dikelas interval 30-39 sebanyak 1 siswa atau $5 \%$.

\section{Hasil Penelitian Siklus I}

Setelah mendapatkan hasil dari prasiklus peneliti harus menerapkan perbaikan pembelajaran siklus I. Hasil yang didapati dari perbaikan pembelajaran siklus I ini sudah mengalami peningkatan. Data peningkatan hasil belajar siswa antara lain siswa yang mendapatkan nilai dikelas interval 50-59 sebanyak 3 siswa atau sekitar 14\%. Siswa yang mendapatkan nilai dikelas interval 60-69 sebanyak 5 siswa atau sebanyak 24\%. Siswa yang mendapatkan nilai dikelas interval 70-79 sebanyak 10 siswa atau sekitar 48\%. Walaupun sudah mengalami peningkatan yang cukup signifikan siswa yang mendapatkan nilai memuaskan yaitu dikelas interval antara 80-89, 90-99, dan nilai 100 masing-masing hanya 1 siswa atau masingmasing sebanyak $5 \%$.

\section{Hasil Penelitian Siklus II}

Hasil belajar yang dicapai dalam siklus I sudah menunjukkan peningkatan yang baik, namun masih perlu ditingkatkan lagi. Setelah diadakan perbaikan pembelajaran siklus II, hasil belajar siswa dalam pembelajaran IPA materi tumbuhan hijau mengalami peningkatan yang memuaskan. Hasil belajar siswa yang diperoleh antara lain, siswa yang tidak tuntas dalam pembelajaran ini hanya 1 siswa atau hanya $5 \%$. Sebanyak 20 siswa yang lainnya telah mencapai nilai di atas KKM (70). Dari kelas interval 70-79 hanya sebanyak 2 siswa atau sebanyak $10 \%$. Siswa yang mendapatkan nilai di kelas interval 80-89 sebanyak 11 siswa atau 52\%. Siswa yang memeroleh nilai pada kelas interval 90-99 sebanyak 2 siswa atau sebanyak $10 \%$, sedangkan siswa yang memerolrh nilai 100 sebanyak 5 siswa atau kira-kira sebanyak $24 \%$.

Pada pembelajaran sebelum siklus, guru mengajar hanya dengan metode ceramah dan sedikit tanya jawab. Di dalam proses pembelajaran hanya guru yang aktif, sedangkan siswa mendengarkan saja penjelasan dari guru. Oleh sebab itulah, suasana yang membosankan nampak pada proses pembelajaran tersebut. Selain itu, perhatian siswa juga tidak fokus. Hal ini diakibatkan ada beberapa siswa yang berbicara sendiri, bercanda, menyandarkan kepalanya di atas meja, dan lain-lain. Hal ini nampaknya membuat pemahaman siswa terhadap materi yang diajarkan guru tidak maksimal diserap oleh siswa. Setelah diadakan evaluasi pembelajaran, hanya beberapa siswa saja yang tuntas belajarnya. Sedangkan sebagian besar siswa lainnya masih mendapatkan nilai di bawah KKM (70).

Di dalam hasil pembelajaran pra siklus, siswa yang tuntas belajarnya hanya berjumlah 4 dari 21 siswa keseluruhan. Dengan kata lain, ketuntasan belajar siswa hanya 19\%. Rata-rata nilai siswa dalam tes formatif

Proses perbaikan pembelajaran siklus I sudah terjadi peningkatan jika dibandingkan dengan sebelum perbaikan. Hal ini dapat dilihat dari jumlah siswa yang tuntas belajarnya sudah meningkat

Dari data kualitas pelaksanaan perbaikan pembelajaran dan hasil tes formatif siswa, yang memanfaatkan model pembelajaran Eksperimen ditemukan dalam penelitian pada mata pelajaran Ilmu Pengetahuan Alam tentang tumbuhan hijau kelas V semester I SD Negeri Babadan, dapat dikatakan bahwa pelaksanaan perbaikan pembelajaran meningkat, dan karena itu prestasi 
belajar siswa juga meningkat. Pelaksanaan perbaikan pembelajaran berjalan dengan cukup baik, nilai terendah 50 dan nilai tertinggi 100 dengan nilai rata-rata kelas 68. Dari hasil tersebut masih ada 8 dari 21 siswa yang belum tuntas belajarnya.

Ketidaktuntasan belajar siswa karena masih ada beberapa siswa belum memahami materi yang dipelajari. Hal ini disebabkan siswa belum memahami penjelasan dari guru karena penjelasan guru terlalu cepat. Selain itu, hanya guru saja yang melakukan eksperimen yaitu proses fotosintesis. Oleh sebab itulah, pada perbaikan pembelajaran berikutnya eksperimen dilakukan menyeluruh untuk kompetensi dasar atau indikator yang akan diajarkan serta menitikberatkan pada keaktifan seluruh siswa.

Pada pelaksanaan perbaikan pembelajaran siklus II, peneliti memusatkan kegiatan pembelajaran pada seluruh siswa, yang memanfaatkan model pembelajaran eksperimen, dengan harapan pelaksanaan perbaikan pembelajaran siklus II ini dapat berhasil dengan baik. Terbukti setelah diadakan tes formatif ada peningkatan taraf serap pada siswa. Dengan nilai terendah 60 dan nilai tertinggi 100. Nilai rata-rata kelas 86. Dengan demikian hasil belajar siswa pada perbaikan pembelajaran siklus II ini mengalami peningkatan yang signifikan dibandingkan dengan pembelajaran pada pra siklus dan siklus I.

Perbandingan hasil ulangan siswa pada pembelajaran pra siklus, Siklus I, dan Siklus Iidijelaskan bahwa sebelum pembelajaran, siswa yang tuntas belajarnya hanya 4 siswa atau 19\%, 17 sisanya tidak tuntas. Pada perbaikan pembelajaran siklus I, siswa yang tuntas belajarnya, sudah meningkat menjadi 13 dari 21 siswa atau sekitar 62\%. Kemudian setelah perbaikan pembelajaran siklus II diperoleh hasil ulangan 20 dari 21 siswa tuntas belajarnya atau sekitar 95\%. Satu siswa yang belum tuntas diberikan bimbingan khusus yang terpisah dari siswa yang lain.

Pada pembelajaran siklus II, peneliti menggunakan model pembelajaran eksperimen pada mata pelajaran Ilmu Pengetahuan Alam yang menitikberatkan pada keaktifan seluruh siswa. Hal ini peneliti lakukan dengan melakukan eksperimen pada seluruh indikator pembelajaran sehingga siswa dapat memahami materi secara total, bukan setengah-setengah. Hasilnya terbukti setelah diadakan tes formatif siklus II dengan ketuntasan sebesar 95\%. Artinya, hanya 1 siswa saja yang belum tuntas belajarnya. Meskipun demikian, pembelajaran ini sudah dapat dikatakan sukses dan tuntas karena prosentase ketuntasan sudah mencapai di atas angka $75 \%$

\section{SIMPULAN}

Melalui penerapan model pembelajaran eksperimen, proses pembelajaran mata pelajaran Ilmu Pengetahuan Alam (IPA) tentang tumbuhan hijau di kelas $\mathrm{V}$ di SD Negeri Babadan Kecamatan Bonang Kabupaten Demak Tahun Pelajaran 2015/2016 berjalan dengan baik dan menyenangkan. Melalui penerapan model pembelajaran eksperimen, prestasi belajar siswa di kelas V di SD Negeri Babadan Kecamatan Bonang Kabupaten Demak Tahun Pelajaran 2015/2016 mata pelajaran Ilmu Pengetahuan Alam (IPA) tentang tumbuhan hijau meningkat dengan signifikan.

\section{DAFTAR PUSTAKA}

Ahmadi, Abu dan Widodo Supriyono. 1991. Psikologi Belajar. Jakarta: Rineka Cipta.

Dahar. 1989. Psikologi Belajar Mengajar. Aksara Citra: Yogyakarta.

Dewiki, Santi. 2009. Pembelajaran Ilmu Pengetahuan Alam SD. Jakarta: Penerbit UT.

Fowler, HW, dkk. 1951. Metode Mengajar IPA. Buana Nusantara: Jakarta.

Latuheru. 1988. Media Pembelajaran SD. Bumi Aksara: Jakarta.

Roestiyah. 2001. Penelitian Tindakan Kelas. Pustaka Jaya: Bandung.

Sagala. 2012. Meningkatkan Pemahaman IPA. Media Pers: Surakarta.

Sardiman. 1990. Interaksi \& Motivasi Belajar Mengajar. Rajawali Pers: Yogyakarta.

Sudjana, Nana. 1989. Dasar-dasar Proses Belajar Mengajar. Bandung : Sinar Baru Algensido Offset.

Sugandi, Achmad. 2004. Teori Pembelajaran. Semarang: IKIP Semarang Press.

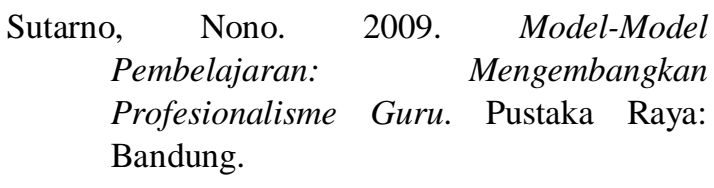


Tim Penyusun KBBI. 2007. Kamus Besar Bahasa Indonesia (edisi ketiga). Jakarta: Balai Pustaka.

UU No. 20 Tahun 2003 tentang Sistem Pendidikan Nasional .

UU No. 14 Tahun 2005 tentang GURU dan DOSEN.

Zaenal, Aqib. 2003. Penerapan Model Pembelajaran Kooperatif. Sari Ilmu: Bandung. 